\title{
RANCANG BANGUN SARUNG TANGAN SEBAGAI ALAT BANTU TUNA NETRA BERBASIS SENSOR ULTRASONIC DAN ARDUINO NANO
}

\section{DESIGN AND REALIZATION A GLOVE AS SUPPORT DEVICE FOR BLIND BASED ON ULTRASONIC SENSOR AND ARDUINO NANO}

\author{
Rahmat Ramadhana ${ }^{1}$, Dwi Andi Nurmantris ${ }^{2}$, Tita Haryanti ${ }^{3}$ \\ 1,2,3Program Studi Teknologi Telekomunikasi, Fakultas Ilmu Terapan, Universitas Telkom, 40257, Bandung, \\ Indonesia \\ ${ }^{1}$ ramadhanarahmat@student.telkomuniversity.ac.id, ${ }^{2}$ dwiandi@telkomuniversity.ac.id, \\ tharyanti@telkomuniversity.ac.id
}

\begin{abstract}
Abstrak
Aksesibilitas adalah desain sebuah bangunan yang menjamin keamanan dan mudah dijangkau oleh semua orang dan tidak terkecuali, termasuk individu dengan disabilitas. Salah satu bentuk aksesibilitas adalah adanya guiding block atau ubin tekstur pemandu yang menjadi penunjuk jalan bagi pejalan kaki tunaneta di tempat umum. Akan tetapi guilding block yang sudah ada terkadang membuat penyadang tuna netra mengalami kecelakaan seperti tertabrak pot atapun tiang listrik. Pada saat ini, alat untuk membantu penyandang tuna netra untuk melakukan aktivitas hanyalah sebuah tongkat yang memiliki panjang $120 \mathrm{~cm}$, Tongkat tersebut memiliki keterbatasan seperti jangkauan alat, tidak dapat mendeteksi berbagai object di sekeliling penyandang dalam waktu yang cepat. Pada penelitian ini telah dibuat sebuah alat berupa sarung tangan untuk membantu dan meringankan aktivitas seperti mengetahui object yang berada di depan para penyandang tuna netra tersebut. Dengan bantuan sensor ultrasonic kemudian di proses menggunakan Arduino nano. Dengan keluaran menghasilkan getaran dan suara yang berasal dari motor dc dan buzzer. Dapat memberitahukan seberapa dekat objek. Hasil pengujian yang dilakukan sebanyak sepuluh kali dalam hal jarak dan delay pada tiga kondisi. Sarung tangan memiliki error yang kecil dalam hal pengukuran jarak tetapi memiliki error rate yang tinggi di setiap object. Kemudian pada pengujian delay didapatkan perbedaan nilai yang sedikit pada object yang berbeda dan pada jarak tertentu dari satu hingga tiga meter didalam tiga kondisi.
\end{abstract}

Kata kunci : Aksesibilitas, Tuna netra, Sarung tangan, Sensor Ultrasonic, Arduino Nano.

\section{Abstract}

Accessibility is the design of a building that guarantees security and is easily accessible to everyone and is no exception, including individuals with disabilities. One form of accessibility is the guiding block or guide texture tiles that guide the blind pedestrians in public places. However, the existing guilding block sometimes makes blind people with accidents such as being hit by pots or electric poles. At this time, the tool to help the blind to do activities is just a stick that has a length of 120 $\mathrm{cm}$, the stick has limitations such as the reach of the tool, can not detect various objects around the person in a fast time. In this research has been made a tool in the form of gloves to help and ease activities such as knowing the object that is in front of the blind people. With the help of ultrasonic sensors then processed using Arduino Nano. With the output produces vibrations and sound coming from the dc motor and buzzer. Can tell how close the object is. The test results were carried out ten times in terms of distance and delay in three conditions. Gloves have a small error in terms of measuring distances but have a high error rate for each object. Then the delay generated by the ultrasonic sensor to vibration changes significantly in each condition, this is influenced by the temperature and conditions around the test.

Keywords: Accessibility, blind, Gloves, Ultrasonic sensor, Arduino nano. 


\section{PENDAHULUAN}

Aksesibilitas adalah desain sebuah bangunan yang menjamin keamanan dan mudah dijangkau oleh semua orang dan tidak terkecuali, termasuk individu dengan disabilitas [1]. Salah satu bentuk aksesibilitas adalah adanya guiding block atau ubin tekstur pemandu yang menjadi penunjuk jalan bagi pejalan kaki penyandang tunanetra di tempat umum [1]. Keberadaan ubin ini sangat penting bagi penyandang tunaneta, karena keterbatasan penglihatan yang mereka alami menyebabkan mereka kesulitan untuk melakukan mobilisasi [1].

Tetapi berbagai jurnal penelitian tentang guilding block terhadap penyandang tuna netra menjelaskan tentang guilding block yang mengarahkan penyandang tuna netra ke tempat yang terhalang seperti tiang listrik, kios pendagang, area parkiran, dan tiang beton [1].

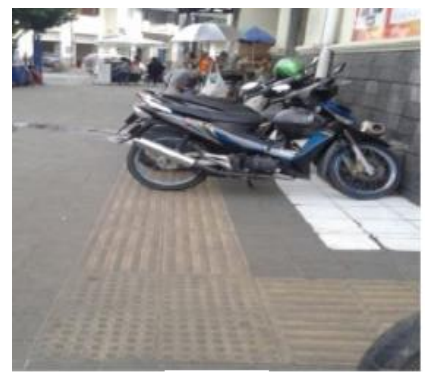

(a)

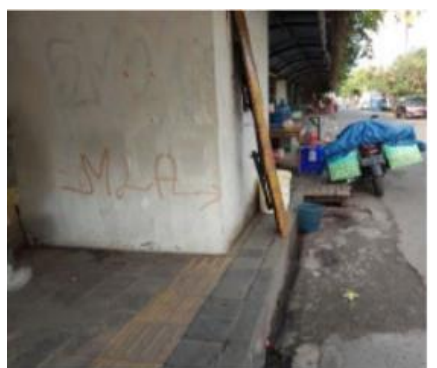

(b)

Gambar 1. Guilding block (a) mengerahkan ke sepeda motor dan

(b) mengarahkan ke tiang beton [1]

Para penyandang tuna netra mengalami kesulitan dalam menjalankan aktivitas sehari - hari serta seringkali mengalami kecelakaan saat beraktivitas dikarenakan alat bantu seadanya dan akses yang kurang memadai.

Menurut survey kepada penyandang tuna netra, para penyandang tuna netra mengalami kecelakaan saat berjalan di trotoar, seperti menabrak tiang listrik, pot tanaman yang terpasang dan lain sebagainya. Dan banyaknya para pengguna sepeda motor yang melintasi trotoar yang membuat para penyandang lebih takut akan berjalan di trotoar.

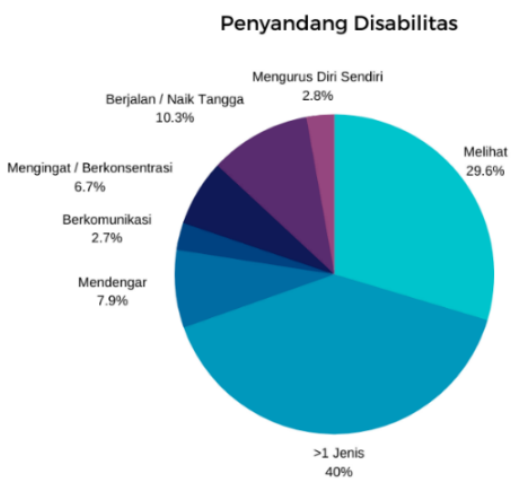

Gambar 2. Grafik Penyandang Disabilitas

Jumlah penyandang tuna netra di Indonesia pada tahun 2017 berjumlah 1.5\% dari jumlah penduduk di indonesia. Pada tahun 2012 Susenas melaporkan bahwa penyandang disabilitas atau keterbatasan terbanyak adalah penyandang yang mengalami lebih dari satu jenis keterbatasan, diikuti keterbatasan melihat (tunanetra) dan berjalan [2]. 
Alat yang digunakan untuk saat ini adalah tongkat pemandu dengan panjang $120 \mathrm{~cm}$ dan tongkat ini memiliki keterbatasan seperti tidak dapat memberitahukan secara cepat jika ada penghalang ataupun benda yang ada didepannya. Penelitian yang dilakukan oleh [3] menggunakan sensor ultrasonic berbasis mikrokontroler mempunyai kekurangan yaitu sensor ultrasonic yang digunakan kurang maksimal dalam mengukur jarak dan mempunyai batas jarak pada penggunaannya. Kemudian penelitian yang dilakukan oleh [4] mempunyai kekurangan yaitu pada pengujian sensor ultrasonic untuk mendeteksi jalan berlubang tidak maksimal. Kemudian penelitian yang dilakukan oleh [5] mempunyai kekurangan seperti kurang presisi untuk mengukur jarak sensor ultrasonic dikarenakan pemakaian sensor ultrasonic yang terlalu banyak. Kemudian penelitian yang dilakukan oleh [6] Menggunakan sensor ultrasonic HC - SR 04 yang memiliki 4 buah diletakan disekeliling ikat pinggang yang menyebabkan bagian yang terdeteksi sensor hanya bagian dari pinggang pengguna tersebut. Kemudian penelitian terakhir yang dilakukan oleh [7] mempunyai keterbatasan dalam mendeteksi jarak hanya sampai $100 \mathrm{~cm}$. Sensor ultrasonic pada jurnal yang dicantumkan pada penelitian ini mendominasi menggunakan sensor ultrasonic HC - SR 04.

Tujuan penelitian ini adalah merancang alat bantu berupa sarung tangan pintar untuk penyandang tuna netra dalam menjalankan aktivitas sehari - hari. Kemudian manfaat yang diberikan penelitian ini adalah dapat membantu permasalahan para penyandang tuna netra dalam menjalankan aktivitas sehari - hari baik aktivitas di dalam maupun di luar ruangan, seperti menghindari benda benda disekitarnya ketika sedang berjalan. Selain itu, alat ini dapat mengurangi resiko kecelakaan serta mudah secara pemakaian.

\section{PERANCANGAN SISTEM}

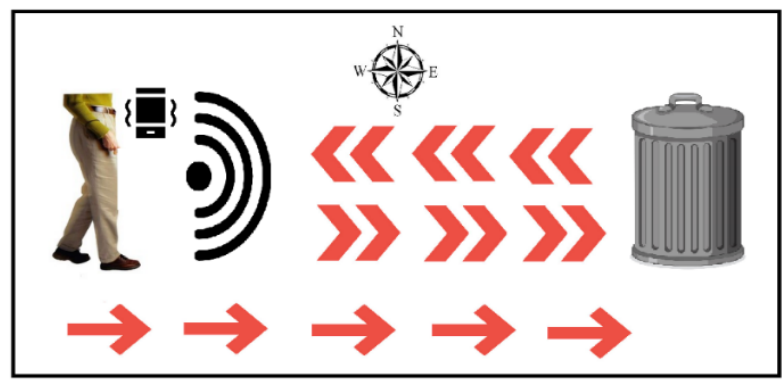

Gambar 3. Skenario perancangan sistem

Pada Gambar 3. menjelaskan skenario perancangan sistem pada penelitian kali ini, dimana saat penyandang tuna netra berjalan ke arah timur terdapat benda ataupun halangan berupa tong sampah, Dimana dapat menimbulkan risiko kecelakaan pada penyandang tuna netra. Kemudian pada sensor ultrasonic secara langsung membaca jarak yang berada tepat didepan penyandang tuna netra tersebut. Kemudian saat sensor ultrasonic mendeteksi bahwa ada benda berada tepat didepannya akan diproses melalui Arduino nano dan memberitahukan berupa getaran ke penyandang tuna netra tersebut sehingga dapat menggurangi risiko kecelakaan.

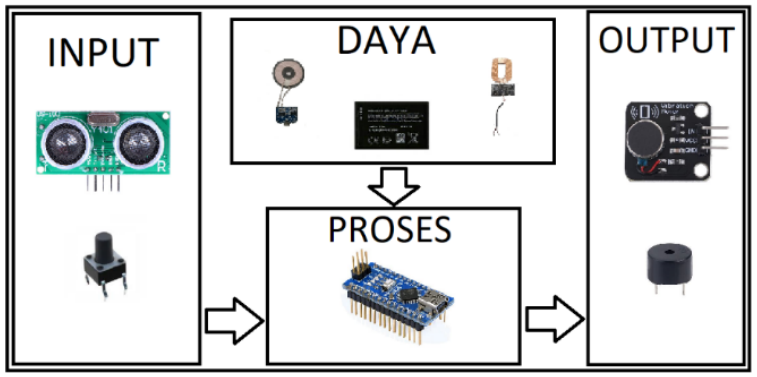

Gambar 4. Perancangan sistem 
Jurnal Elektro Telekomunikasi Terapan Desember 2020

Pada perancangan sistem ini, yang digunakan adalah perangkat sensor ultrasonic us - 100 yang digunakan untuk mengukur jarak dari penyandang tuna netra ke objek yang berada tepat di depannya. Kemudian vibration akan menghasilkan getaran untuk memberitahukan penyandang tuna netra jika ada objek yang berada tepat didepannya. Push button dan buzzer digunakan untuk mengatur jarak aman dan memberitahukan jarak aman kepada penyandang tuna netra. Untuk pengisian daya perangkat tersebut menggunakan wireless charging yang dibantu dengan perangkat TP 4065 sebagai modul charger daya dan DC Power supply sebagai daya untuk menghidupkan Arduino nano. Semua perangkat tersebut disimpan didalam black box ukuran $75 \times 50 \times 25 \mathrm{~mm}$.

\subsection{Model sistem}

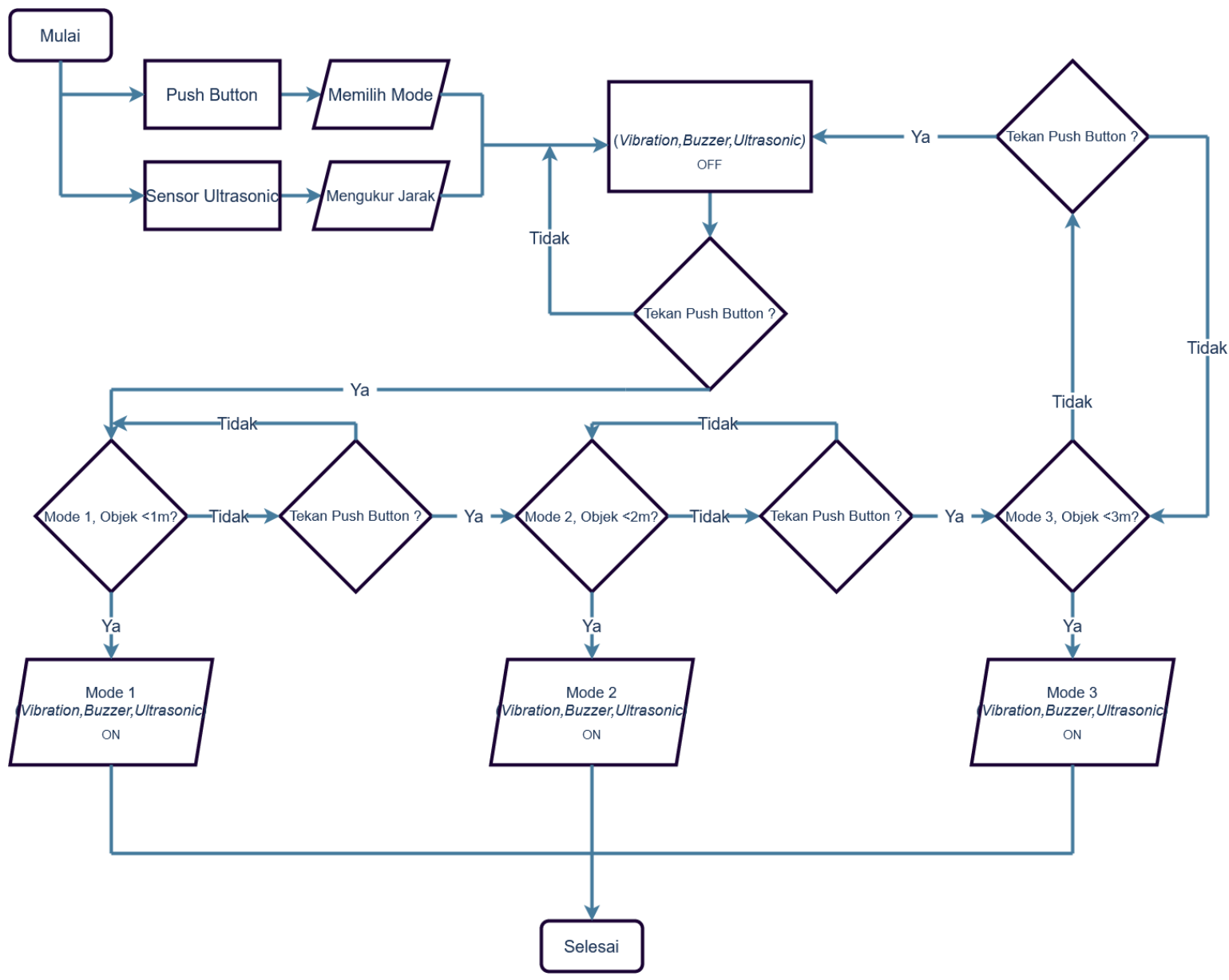

Gambar 5. Flowchart cara kerja sistem sarung tangan

Pada sistem kerja sarung tangan, terdapat dua input pada sistem berupa sensor ultrasonic dan push button, kemudian push button tersebut sebagai alat untuk mengganti mode dari mode 1 hingga mode tiga tergantung penyandang tuna netra saat memakainya. Saat di mode satu maka Arduino nano memerintahkan sensor ultrasonic akan memberikan peringatan berupa getaran, jika ada object yang kurang dari 1 meter dan seterusnya hingga mode ketiga.

\subsection{Rangkaian perangkat}

Pada penelitian ini rangkaian perangkat yang dibuat sebagai tahap akhir dalam pembuatan alat tersebut. Dalam hal ini modul ataupun sensor dipasang sesuai dengan sistem yang dibuat. Berikut rangkaian perangkat dapat dilihat pada gambar 


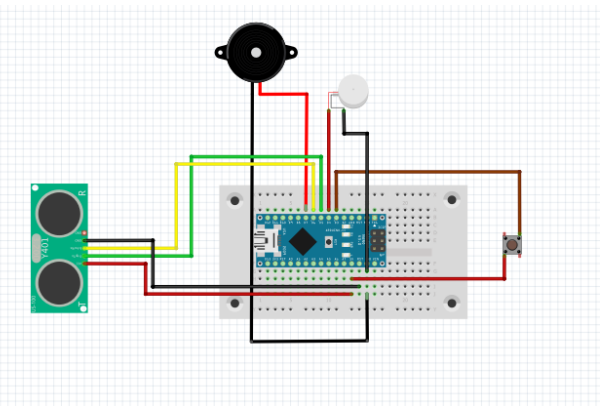

Gambar 6. Rangkaian perangkat

Pada sensor ultrasonic terdapat pin VCC, Echo/Tx,Trig/RX dan GND. Pin VCC terhubung dengan pin 5v pada Arduino nano, kemudian pin Echo/TX terhubung dengan pin D5 Arduino nano, lalu pada pin Trig/TX terhubung dengan pin D6 Arduino nano, Dan yang terakhir pin GND terhubung dengan GND pada Arduino nano. Kemudian pada push button salah satu kaki bagian kanan bawah terhubung dengan pin 5v pada Arduino nano, lalu pada kaki bagian kiri atas terhubung dengan pin D3 pada Arduino nano. Pada vibration pin atau kaki positif terhubung dengan pin D4 dan kemudian pin negative terhubung dengan GND pada Arduino nano. Pada buzzer pin positif terhubung dengan pin D7 dan pin negative terhubung dengan GND pada Arduino nano.

\section{HASIL PERANCANGAN DAN SIMULASI}

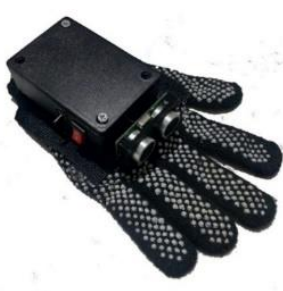

(a)

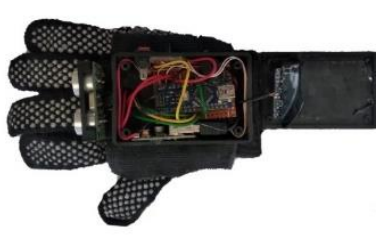

(b)

Gambar 7. Sarung tangan (a) tampilan dari sisi kiri atas dan (b) bagian dalam dari box hitam

Pada pengujian kali ini akan dilakukan dua pengujian, yang pertama pengujian jarak dan yang kedua pengujian delay. Pengujian jarak ini diharapkan seberapa presisi sensor ultrasonic US - 100 dalam membaca jarak yang sudah ditentukan pada pengujian kali ini. Kemudian pengujian delay kali ini dilakukan untuk melihat delay output getaran dari hasil jarak yang sudah di tentukan dari satu meter hingga tiga meter.

\subsection{Pengukuran Jarak}

Pada pengujian jarak kali ini sebuah sensor ultrasonic US - 100 akan diletakan pada jarak satu meter hingga tiga meter, kemudian alat tersebut akan dihubungkan ke perangkat laptop yang sudah terinstal Arduino IDE untuk melihat jarak yang didapatkan pada option serial monitor, pengujian jarak dilakukan sebanyak sepuluh kali percobaan dan berikut hasil rata - rata yang didapatkan pada Tabel 1. 
Jurnal Elektro Telekomunikasi Terapan Desember 2020

Tabel 1. Nilai rata - rata jarak sensor ultrasonic

\begin{tabular}{|c|c|c|c|c|c|c|}
\hline Jarak Asli & (Kayu) & (Batu) & (Kaca) & (Plastik) & (Besi) & (Logam) \\
\hline $100 \mathrm{CM}$ & $98.5 \mathrm{CM}$ & $100 \mathrm{CM}$ & $100.8 \mathrm{CM}$ & $100 \mathrm{CM}$ & $99.1 \mathrm{CM}$ & $100.6 \mathrm{CM}$ \\
\hline $200 \mathrm{CM}$ & $199.7 \mathrm{CM}$ & $200.3 \mathrm{CM}$ & $200 \mathrm{CM}$ & $200 \mathrm{CM}$ & $199.8 \mathrm{CM}$ & $200.2 \mathrm{CM}$ \\
\hline $300 \mathrm{CM}$ & $300 \mathrm{CM}$ & $300.5 \mathrm{CM}$ & $299.8 \mathrm{CM}$ & $301.8 \mathrm{CM}$ & $300 \mathrm{CM}$ & $300.1 \mathrm{CM}$ \\
\hline
\end{tabular}

Dari nilai rata - rata hasil yang didapatkan terdapat nilai dari jarak yang didapatkan tidak sesuai dengan pengukuran. Seperti pada object kayu didapatkan hasil rata - rata $98.5 \mathrm{~cm}$ dan 199.7 $\mathrm{cm}$ dengan error rate 30\% dan 30\% dari sepuluh kali percobaan, kemudian object batu $200.3 \mathrm{~cm}$ dan $300.5 \mathrm{~cm}$ dengan error rate $30 \%$ dan $50 \%$ dari sepuluh kali percobaan. Kemudian object kaca dengan nilai jarak $100.8 \mathrm{~cm}$ dan $299.8 \mathrm{~cm}$ dengan error rate $30 \%$ dan $20 \%$. kemudian pada object plastic memilik nilai jarak yang paling salah dengan $301.8 \mathrm{~cm}$ dengan error rate $70 \%$ kemudian pada object besi $99.1 \mathrm{~cm}$ dan $199.8 \mathrm{~cm}$ memiliki error rate $60 \%$ dan $20 \%$ dari sepuluh kali percobaan. Dan yang terakhir pada object logam mempunyai nilai $100.6 \mathrm{~cm}, 200.2 \mathrm{~cm}$ dan $300.1 \mathrm{~cm}$ dengan error rate $60 \%, 20 \%$ dan $10 \%$ dari sepuluh kali percobaan. Sensor ultrasonic beberapa kali salah membaca nilai jarak object tersebut.

\subsection{Pengukuran Delay}

Pada pengujian delay kali ini sebuah sensor ultrasonic US - 100 didalam sarung tangan tersebut akan diletakan sesuai tiga titik, yaitu titik pertama satu meter, titik kedua yaitu dua meter dan titik terakhir tiga meter. Kemudian dari jarak tersebut akan diberikan halangan atau obstacle. Pengujian ini dilakukan untuk menghitung respon vibration dalam memberikan informasi. Dalam pengujian deteksi kali ini dilakukan sepuluh kali percobaan dalam tiga kondisi yaitu pagi hari pada pukul tujuh waktu Indonesia barat, kemudian pada siang hari pukul dua belas dan yang terakhir pada malam hari pukul tujuh. Tempat pengujian berlokasi dihalaman rumah penulis. Dan berikut merupakan rata - rata respon waktu yang didapatkan pada tiga kondisi.

Tabel 2. Nilai Rata - rata delay vibration pada pagi hari

\begin{tabular}{|c|c|c|c|c|c|c|}
\hline Jarak & (Kayu) & (Batu) & (Kaca) & (Plastik) & (Besi) & (Logam) \\
\hline$<100 \mathrm{CM}$ & 0.565 & 0.566 & 0.532 & 0.523 & 0.524 & 0.494 \\
\hline$<200 \mathrm{CM}$ & 0.590 & 0.606 & 0.585 & 0.586 & 0.556 & 0.573 \\
\hline$<300 \mathrm{CM}$ & 0.636 & 0.557 & 0.582 & 0.576 & 0.641 & 0.553 \\
\hline
\end{tabular}

Tabel 3. Nilai Rata - rata delay vibration pada siang hari

\begin{tabular}{|c|c|c|c|c|c|c|}
\hline Jarak & (Kayu) & (Batu) & (Kaca) & (Plastik) & (Besi) & (Logam) \\
\hline$<100 \mathrm{CM}$ & 0.537 & 0.525 & 0.524 & 0.552 & 0.551 & 0.542 \\
\hline$<200 \mathrm{CM}$ & 0.552 & 0.492 & 0.499 & 0.537 & 0.542 & 0.533 \\
\hline$<300 \mathrm{CM}$ & 0.530 & 0.554 & 0.575 & 0.540 & 0.572 & 0.525 \\
\hline
\end{tabular}


Jurnal Elektro Telekomunikasi Terapan Desember 2020

Tabel 4. Nilai Rata - rata delay vibration pada malam hari

\begin{tabular}{|c|c|c|c|c|c|c|}
\hline Jarak & (Kayu) & (Batu) & (Kaca) & (Plastik) & (Besi) & (Logam) \\
\hline$<100 \mathrm{CM}$ & 0.496 & 0.532 & 0.478 & 0.532 & 0.501 & 0.504 \\
\hline$<200 \mathrm{CM}$ & 0.505 & 0.539 & 0.424 & 0.520 & 0.475 & 0.495 \\
\hline$<300 \mathrm{CM}$ & 0.512 & 0.515 & 0.563 & 0.489 & 0.559 & 0.545 \\
\hline
\end{tabular}

Pada nilai delay yang didapatkan dalam tiga kondisi, tiap kondisi dan object memiliki nilai yang sedikit sama, pada object yang berbeda dan pada jarak satu meter di dalam tiga kondisi didapatkan nilai sebesar 0.526 detik. Kemudian pada jarak dua meter dengan object yang berbeda didapatkan nilai sebesar 0.533 detik. Dan yang terakhir pada jarak tiga meter dengan object yang berbeda didapatkan nilai sebesar 0.556 detik. Dari ketiga kondisi tersebut memiliki perbedaan nilai yang sangat kecil.

\subsection{Kuisioner}

Pada kuisoner kali ini dilakukan untuk mendapatkan pendapat terhadap penyandang tuna netra. Dari segi fungsionalitas kemudian seberapa dibutuhkannya alat yang dibuat dan masukan untuk alat selanjutnya. Pada penelitian kali ini, Survey ini dilakukan di Panti Sosial Bina Netra (PSBN) Tan Miyat Bekasi. Dengan mengikuti aturan di tempat tersebut, maka nama dalam kuisioner hanya dituliskan inisial dari nama pengisi kuisioner tersebut.

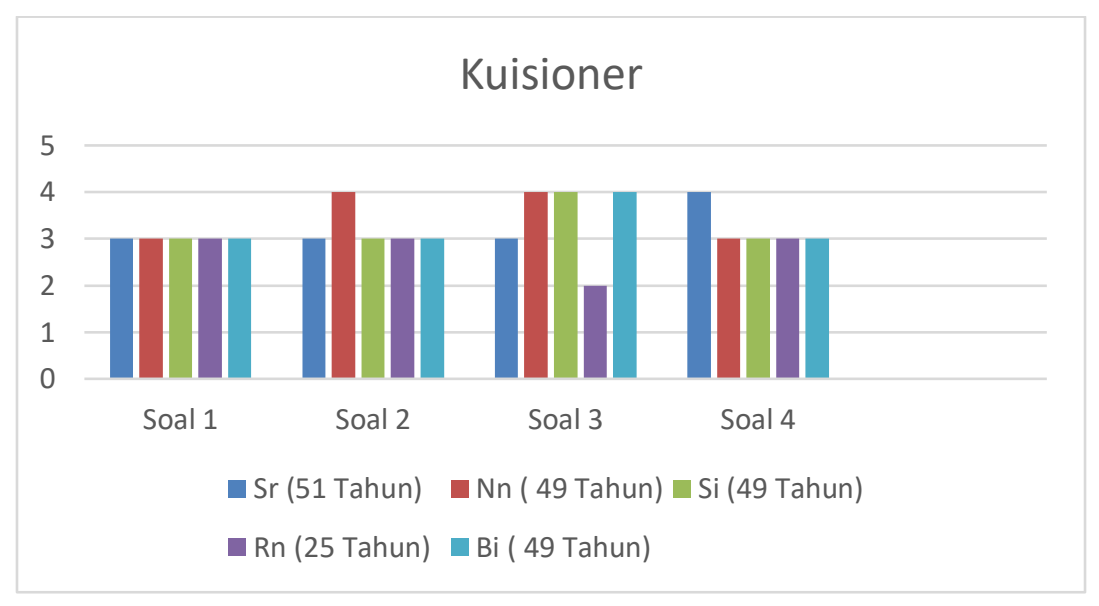

Gambar 8. Grafik Kuisioner tanggapan penyandang tuna netra.

Pada survei yang sudah dilakukan, Para penyandang tuna netra memberikan saran untuk kedepannya dalam hal menambahkan kapasitas baterai karena perangkat yang sekarang tidak terlalu lama dalam penggunaannya, kemudian para penyandang tuna netra memberikan saran untuk dapat membedakan objek seperti adanya lubang, tembok, tangga dan lainnya.

\section{KESIMPULAN}

Hasil dari dua pengujian pada penlitian ini didapatkan bahwa sensor ultrasonic US-100 mempunyai error rate yang tinggi pada object tertentu, Hal ini bisa terjadi karena ada beberapa faktor seperti suhu pada waktu pengukuran dan permukaan object. Pada pengujian delay dengan yang berbeda object dan kondisi didapatkan nilai tersebut memiliki perbedaan yang sangat kecil. Dan dapat membuktikan bahwa dalam memberikan informasi kepada penyandang tuna netra lebih responsif. Kemudian dalam survei yang dilakukan kepada para penyandang tuna netra menilai bahwa 
alat yang dibuat pada penelitian ini dapat berguna ditempat umum dan dibutuhkan para penyandang tuna netra dalam menjalankan aktivitas seperti berjalan ke masjid, aula dan tempat lain yang berada di lingkungan Panti Sosial Bina Netra (PSBN) Tan Miyat Bekasi. Berdasarkan hasil pembangunan penelitian ini, dapat disampaikan beberapa saran untuk pengembangan penelitian selanjutnya yaitu: (i) menambahkan informasi berupa suara ketika penyandang tuna netra meletakkan perangkat transmitter charging dan receiver charging dengan benar disarung tangan tersebut, (ii) menambahkan informasi berupa suara ketika baterai lemah dan baterai penuh, (iii) menambahkan informasi berupa suara atau hal lainnya untuk memberitahukan perangkat tersebut dalam kondisi menyala atau aktif.

\section{DAFTAR PUSTAKA}

[1] Khoiurnisa, Esdaniar dan Hirmawanto, Dwi, Aris.2018. Perbandingan Ketersediaan Ubin Tekstur Pemandu untuk Tuna Netra di Tempat Umum antara Kota Surakarta dan Kota Nagoya.Surakarta. Universitas Sebelas Maret.

[2] InfoDATIN Pusat Data dan Informasi Kementerian Kesehatan RI, 2012.

[3] Mustofa, Aziz. Febianda, Bagus, Bintang. Permatasari, Cornelia, Donarvi. Pratiwi, Yani, Eka. Beta, Samuel.2018. Sarung Tangan Untuk Tuna Netra. Semarang. Politeknik Negeri Semarang.

[4] Pamungkas, Tunas, Bintar.2013. Rancang Bangun Tongkat Ultrasonik Pendeteksi Halangan dan Jalan Berlubang untuk Penyandang Tunanetra berbasis ATMEGA 16. Yogyakarta. Universitas Negeri Yogyakarta.

[5] Faruk, Zainal.2017. Rancang Bangun Alat Bantu Jalan Tuna Netra Dengan Tongkat Cerdas Berbasis Arduino. Malang. Institut Teknologi Nasional Malang.

[6] Al-Hasan, Muhammad, N. Parta, Cok, Indra. Divayana, Yoga. Rancang Bangun Pemandu Tuna Netra Menggunakan Sensor Ultrasonik Berbasis Mikrokontroler. Bali. Universitas Udayana.

[7] Kurniawan, Asep. 2019. Alat Bantu Jalan Sensorik Bagi Penyandang Tunanetra. Journal of Disability Studies.6:2 285-312.

[8] 4muda. 2015. Kecepatan suara dalam berbagai medium dan bagaimana proses telinga mendengar suara. [Online] Tersedia di https://www.4muda.com/kecepatan-suara-dalamberagam-medium-dan-bagaimana-proses-telinga-mendengar-suara/.[ diakses pada 28 Agustus 2020]

[9] C-1 Foundation. 2020. Speed Of Sound. [Online] Tersedia di https://www.ck12.org/physics/speed-of-sound/lesson/Speed-of-Sound-MSPS/?referrer=concept_details. [ diakses pada 28 Agustus 2020].

[10] NDT Resource Center. Sound. Tersedia di https://www.ndeed.org/EducationResources/HighSchool/Sound/hs_sound_index.php. [ diakses pada 28 Agustus 2020] 